Article

\title{
From Power to Legitimacy-Explaining Historical and Contemporary Water Conflict at Yesa Reservoir (Spain) and Gross Reservoir (USA) Using Path Dependency
}

\author{
Laura Turley (D)
}

Citation: Turley, L. From Power to Legitimacy-Explaining Historical and Contemporary Water Conflict at Yesa Reservoir (Spain) and Gross Reservoir (USA) Using Path Dependency. Sustainability 2021, 13, 9305. https://doi.org/10.3390/ su13169305

Academic Editor: Antonio Boggia

Received: 31 May 2021

Accepted: 27 July 2021

Published: 19 August 2021

Publisher's Note: MDPI stays neutral with regard to jurisdictional claims in published maps and institutional affiliations.

Copyright: (C) 2021 by the author. Licensee MDPI, Basel, Switzerland. This article is an open access article distributed under the terms and conditions of the Creative Commons Attribution (CC BY) license (https:/ / creativecommons.org/licenses/by/ $4.0 /)$.
Environmental Governance and Territorial Development Hub, Institute for Environmental Sciences, University of Geneva, 1205 Geneva, Switzerland; laura.turley@unige.ch

\begin{abstract}
Conflict over new dams and reservoirs is well-studied, but less is known about controversies over the reoperation of existing water infrastructure. This paper presents two cases of reoperation that have been embroiled in conflict: the Gross Reservoir Expansion Project in Colorado, United States, and the Yesa Reservoir Regrowth project in Aragon and Navarra, Spain. A historical analysis of each of the cases relies on process tracing, reaching back to their construction in the 1950s up to present day, and a cross-case comparison distills findings on the causes of historical and contemporary conflict. The paper adds empirical evidence to the phenomenon of path dependency, and argues that a transition of the dominant mechanism of institutional reproduction occurs in the cases-from power to legitimacy-which in turn informs us about the historical and present-day conflicts. We find that through the contemporary reoperation, water service providers are experiencing a legitimacy crisis related to the quickly-evolving values of water users, and their access to competing sources of knowledge and expertise.
\end{abstract}

Keywords: water conflict; path dependence; power; legitimacy; Gross Reservoir; Yesa Reservoir

\section{Introduction}

Controversy surrounding the construction of new dams and reservoirs is almost ubiquitous, culminating at the end of the 20th century in multilateral efforts to improve their planning and construction [1], though many contentious issues remain in the 21st century "dam resurgence era" [2,3]. However, it is not only the development of new infrastructure that can become embroiled in conflict, as this paper draws attention to, but also the reoperation of existing dams and reservoirs. Whereas reoperation, which might involve changes to releases or storage volumes at existing sites, can be considered a more "soft approach" or adaptive measure in comparison to building new infrastructure [4,5], it can be subject to the same debates, which evolve over time, about the most environmentally, socially, and economically responsible way to ensure a reliable water supply.

In order to unpack and understand conflict over reservoir reoperation, in spite of its relative advantages over building new infrastructure, this paper investigates two controversial cases of reoperation: the Gross Reservoir Expansion Project in Colorado, United States, and the Yesa Reservoir Regrowth project in Aragon and Navarra, Spain. The cases have much in common; reservoirs constructed in the 1950s under governance regimes promoting supply-side solutions, closely tied to nation-building and economic development, they have historically gone through periods of intense and high-profile conflict. Today, however, water governance regimes in Spain and the United States espouse principles of stakeholder participation, social dialogue, efficiency, and combining supply- and demand-side approaches to management. The contemporary conflicts center around project justification, particularly in terms of whether or not growing urban water demand requires additional supply, with both sides of the debates making value-laden arguments and relying on (differing) scientific expertise. The questions that this paper is concerned with are the 
following: What are the historical and contemporary causes of conflict surrounding the reservoirs, and how are they related? Is the current conflict indicative of a legitimacy crisis for water providers?

These questions lend themselves to a historical approach, which is valuable for understanding complex social phenomena, and for testing theory on processes that unfold over time [6]. It is also ripe territory for understanding the persistence of institutions through the analytical lens of path dependency, and its causal role in contemporary water allocation conflict. In addition, whereas many previous studies have used path dependency to study water institutions and infrastructure systems [7-11], the reoperation of reservoirs has not been examined from this perspective. Moreover, this article's investigation and explicit identification of underlying mechanisms of institutional reproduction and use of process tracing to develop a causal story add value to the theoretical and methodological scholarship on water institutions and conflict. Finally, this paper brings attention to the role of legitimacy in maintaining the institutional status quo and leading to conflict, as actors call into question the appropriateness of established institutions for determining and allocating water, which are increasingly in juxtaposition to changing values held by key user groups.

The structure of the paper is as follows. Section 2 will present a review of the literature on historical institutionalism, path dependency, and the causal mechanisms that have been developed to explain sequences of institutional reproduction, particularly in water governance studies. There will also be a non-exhaustive review of the concept of legitimacy, followed by the research hypotheses. Section 3 will describe the case study methods used for analyzing data within and across the two cases. Section 4 will present the case studies in some detail, with each broken into four key time periods. Finally, Section 5 discusses the cross-case comparison and, using a visual schema, synthesizes similarities in the cases to respond to the research questions, drawing on a causal story that evolves over time, before a brief conclusion (Section 6).

\section{Literature Review}

\subsection{Identifying and Explaining a Case of Path Dependency}

Historical institutionalism focuses on the creation, persistence, and change of institutions over time. In this discipline, actors and organizations act within institutional arrangements whose structure and functioning can only be fully-or at least better-understood when embedded in a historical perspective [12,13]. Studies from historical institutionalism typically offer a detailed investigation of carefully chosen, comparatively informed case studies for uncovering sources of stability and change [14].

Historical institutionalism is closely associated with the concept of path dependency. Together these approaches create a theoretical framework and provide analytical tools for the study of institutional continuity and change [15]. Mahoney [16] defines path dependency as "historical sequences in which contingent events set into motion institutional patterns or event chains that have deterministic properties" (p. 508). In a path-dependent process, the trajectory of activities and institutional development up to a certain point tends to constrain the trajectory after that point, which can have the effect of generating, or reproducing, institutional inertia [13]. Dynamics of reproduction and change can come from forces that are internal or external to the institutions-the former from the members' knowledge and skills reflecting the payoffs embedded in the institutions, and the latter from the way knowledge influences the perceptions people have about the world around them and how they justify that world [17]. The classic explanation for the stability that defines path dependency has been the concept of increasing returns-borrowed from economics and applied to institutions [17] and public policy [6]. With increasing returns, also referred to as positive feedback in the literature, once an institution is adopted it brings increasing benefits to certain actors. This, in turn, makes the institution more and more difficult to transform or abandon, referred to as "lock-in" even if it becomes inefficient compared to alternatives [16]. 
Although there is a significant amount of grey and academic literature using the terms "pathways" and "paths of development" to explain a phenomenon's evolution and frame future options, it does not mean that a study examines path dependence. Path-dependent processes have two defining features: (1) a contingent departure point, which is an event that is not determined by more general trends or laws, followed by (2) a series of events with proven and explicable causal events [16]. The contingent event is, for all intents and purposes, an accident, or an event that laws and/or one's theory of interest cannot explain. Examples are assassinations, inventions, natural disasters, or simply a choice between equally probable alternatives. This provides the starting point for an analysis of the subsequent self-reinforcing mechanisms of institutions that capitalize (though not necessarily intentionally) on their early advantage, and as such stably reproduce over time. As institutions are generally understood as enduring entities that cannot be changed quickly or easily, this persistence makes them a useful object of inquiry for understanding such self-reinforcing sequences [16]. As such, the causes of the origin of an institution are different from the processes responsible for the reproduction of the institution [16] Pflieger et al. [18] refer to this as the "inherent paradox" of path dependency, where the beginnings of the path are accidental and inexplicable with the theory, whereas the reproduction processes that follow can be explained by traditional theoretical and analytical frameworks.

In addition to identifying these two features, the claim that a political process is path dependent also requires explicitly specifying the causal mechanisms or specific positive feedback effects involved. It is through the identification of such mechanisms that arguments about the temporal processes are made more convincing and theoretically robust, while also providing more systematic explanation and potential comparison to other similar cases $[6,15]$. Without this, path dependency studies risk being limited to simple claims that "history matters" without a clear account of decision making over time [13,15]. Appendix A lists and describes a selection of causal mechanisms found in path dependency studies. Some rely on the increasing returns notion, but others do not. Although path dependency and its explanations are criticized for explaining institutional stability better than institutional change [13], Pierson [6] argues that path dependency does not imply that pathways are permanently locked in, but instead offers that change continues until something "erodes or swamps" the mechanisms of reproduction.

\subsection{Mechanisms of Path Dependency in Water Governance Literature}

Institutions that operate in conjunction with large infrastructure systems, such as water storage and distribution systems, are particularly prone to path dependency. Large technical systems are often characterized by high levels of interdependence, long time horizons, and sunk costs that make the cost of reversal or exit a major impediment to change, which can lead to the self-perpetuation (from positive feedback) of governing institutions and to lock-in. This has been the case for water infrastructure and institutions in many instances [7-11]. Notably, the physicality or materiality of infrastructure (dams, channels etc.) make it difficult to modify, as do the natural constraints (climate, topography, etc.), and planning and finance cycles that typically take place on decadal or multi-decennial scales [12]. There are similar observations from other infrastructure-heavy sectors like urban transport, where physical spaces themselves can become embedded in processes of inertia due to existing infrastructure networks and policy [18]. Martin and Sunley [19] argue, therefore, that many studies of path dependence have a deeply local and physical dimension to their form and operation, and should therefore be understood as "place dependent".

Previous studies describe how the political and economic institutions underlying infrastructure systems can be as deeply rooted and difficult to change, or even more so, than the infrastructure they underlie. The powerful institutions and constituencies that oversaw the construction of massive irrigation infrastructure schemes in countries like Spain, the USA, and Australia, referred to as "hydraulic bureaucracies" are early alliances that have proven a strong ability to protect their interests and to persist in the face of external 
threats $[8,11,20,21]$. Another focus is the pervasiveness of prior appropriation regimes, or "first in time first in right" systems of property rights to water. Originally designed in conjunction with big infrastructure to spur agricultural development in arid and semiarid regions, prior appropriation regimes have proven particularly rigid and resistant to reform. Such regimes have been studied in the context of Alberta [22], California [7], and Montana [23]. Heinmiller [9] looks at the apportionment institutions (rules that establish diversion of resource flows) in three semi-arid river basins, which have proven strongly path dependent and hampered collective action in favor of conservation. Although conservation institutions were eventually adopted, their rules were built around the existing prior apportionment institutions [9]. As such, mechanisms such as power and formal water allocation rules have been essential for explaining reproduction in previous studies of water management, particularly in arid and semi-arid regions.

Values and beliefs have also proven to be an important consideration in explaining both continuity and change in infrastructure-heavy water regimes. In Spain, the core belief underlying the "traditional hydraulic paradigm" as the necessity for human alteration of the environment for modernization has been resistant, but not impervious, to change [24]. Similarly, Parsons et al. [25] describe how path dependency in flood risk management institutions in New Zealand has depended on advancing Western values of command-andcontrol, while marginalizing indigenous values from environmental governance and policy. When the dominant water institutions and/or infrastructure are no longer fit for purpose, and fall out of sync with the values held by stakeholders, it can lead to conflict over the right way forward $[7,8]$. As such, path dependency is a concept that can go a long way in explaining implementation challenges in water reforms (e.g., rights reform), adaptations (e.g., to climate change), or transitions to new paradigms (e.g., IWRM, water security, Nexus), and explaining to what extent past choices might realistically be influencing future trajectories $[7,12,22,26]$.

\subsection{Legitimacy as a Mechanism of Institutional Reproduction and Source of Conflict}

Building on the literature presented above, factors that have proven influential in historical water governance and path dependency studies center around power, formal institutions, participation, and values. In this section we add the legitimacy of institutions to the list. Although the literature on legitimacy in water governance, especially collaborative approaches, is voluminous (see Melnychuk [27] for a comprehensive overview), legitimation has seldom been explored as an explicit cause of institutional reproduction or conflict in historical water governance studies. We anticipate, however, that it has strong explanatory power in understanding why water providers continue along certain trajectories, maintaining institutions by advancing their role as "appropriate" with the "correct" solutions. Particularly as water provision is both an essential and highly complex service, exposed to changes in the socio-ecological system beyond their control such as climatic and hydrological risks, and also population growth, it is not surprising that bulk water providers may rely on tried and trusted approaches. However, the theory informs us that these institutions are vulnerable to changing values and expectations about what is perceived as appropriate [16].

There are rich insights into legitimacy and water governance in the broader literature [28-31]. The question of who makes decisions is a focus, with the so-called "democratization of water management" that has occurred in many countries leading to the emergence of new forums and structures for user and stakeholder participation-bringing with it issues around where to draw the "boundaries of consent" [29]. Similarly, collaborative governance is increasingly used as an alternative to traditional top-down approaches, involving different government levels, users, civil society, and businesses to address water issues, and legitimacy is a critical factor for their effectiveness and approval [27]. Collaboration in itself, however, is not a guarantee that institutions will be accepted by wider society, and collaborative water governance efforts must build legitimacy through substantive and procedural avenues [31]. In terms of water service provision, the "horizontalization" 
of management structures, whereby service providers are increasingly separate from the state, also raises important legitimacy questions about who is ultimately accountable to end users [30].

There exist many typologies of legitimacy, which suggests that legitimacy may be achieved through a number of different sources and studied many different ways [27]. An often-cited distinction is made between input and output legitimacy [32], wherein the input dimension is about participation in decision-making and representation, whereas the output dimension is about results, or the performance of eventual outcomes. Input and output legitimacy are closely connected; legitimacy can neither be attained by inclusion nor by effectiveness alone [33]. Moreover, these dimensions interact, and can be complementary, whereby less of one may be offset by better quality in the other, or lead to trade-offs whereby increasing one necessarily leads to a decrease in the other [34].

Although we focus on the legitimacy of institutions, they are undeniably embedded in a larger social, political, and ecological context, which is constantly in flux. Legitimacy is therefore a deeply social concept [28]. This also makes it a "potentially volatile attribute" as it is always up for reevaluation in changing contexts and amidst changing values [28]. Closely related to its social nature, legitimacy is not a static phenomenon [35]. Sources that helped legitimize actors or activities at one point in time may not be pertinent at later stages. Linking back to the path dependency literature, the legitimation mechanism described by Mahoney [16] occurs when actors feel institutions are morally just or appropriate, which is dependent on values in a certain place and time.

Finally, legitimacy is closely related to the concept of power. In his seminal work, Beetham [36] describes that:

Legitimacy should be understood as a multi-dimensional concept, comprising rules, normative beliefs, and appropriate actions. Power can be said to be legitimate where it does not breach the established rules; where its acquisition and exercise are normatively validated in terms of socially accepted beliefs about rightful authorization and due performance; and where it is confirmed through appropriate acts of recognition and acknowledgement (xiv).

As such, in the subsequent analysis we understand power as predominantly structural, underlain by institutions that determine what actors have the capacity to do. Legitimacy, on the other hand, is a potential attribute of power, based on whether or not it is perceived as correct and proper, and is deeply dependent on values in a given place and time, and can refer to inputs and/or outputs of decision-making. In terms of the structure-agency debates, this approach takes more of a middle ground, that social action cannot be fully explained by the structure or agency theories alone [37]. Although actors operate within the context of rules produced by social structures, these structures are socially constructed and are therefore not immutable [37]. Leveraging concepts from the path dependency literature, Table 1 outlines the power and legitimation mechanisms that will be mobilized in the analysis of the cases, and their potential characteristics and mechanisms of change.

Table 1. Typology of path-dependent explanations of institutional reproduction.

\begin{tabular}{ccc}
\hline & Power Explanation & Legitimation Explanation \\
\hline $\begin{array}{c}\text { Mechanism of } \\
\text { reproduction }\end{array}$ & $\begin{array}{c}\text { Institution is reproduced because it is } \\
\text { supported by a privileged group of } \\
\text { actors, working through inclusion and } \\
\text { exclusion of actors in decision-making. }\end{array}$ & $\begin{array}{c}\text { Institution is reproduced because actors } \\
\text { believe it is morally just or appropriate. }\end{array}$ \\
Potential characteristics of institution & $\begin{array}{c}\text { Institution may empower a group that } \\
\text { was previously subordinate. }\end{array}$ & $\begin{array}{c}\text { Institution may be less consistent with } \\
\text { values of actors than previously available } \\
\text { alternatives. }\end{array}$ \\
Mechanism of change & $\begin{array}{c}\text { Strengthening of subordinate groups and } \\
\text { weakening of privileged groups. }\end{array}$ & $\begin{array}{c}\text { Changes in the values or } \\
\text { subjective beliefs of actors. }\end{array}$ \\
\hline
\end{tabular}




\subsection{Research Hypotheses}

In line with the literature presented above, it is expected that power, understood as how the structure of institutions enables inclusion and exclusion in decision-making, is the dominant mechanism for institutional reproduction in the cases historically (Hypothesis 1). This is particularly related to the establishment of early apportionment institutions and the lasting benefits derived from connections to the storage and distribution infrastructure. However, when the balance of power is challenged, which could in theory lead to institutional change $[15,38]$, we suggest that a legitimation mechanism of institutional reproduction emerges and ultimately serves to maintain the status quo, as institutions and the actors they support are advanced on the basis of their appropriateness for dealing with water supply challenges (Hypothesis 2). As such, the contemporary conflict is best characterized as a legitimacy crisis for water providers, driven by divergent values, competing knowledge of the resource system, and disagreement over what trade-offs are acceptable or appropriate to ensure a reliable water supply (Hypothesis 3).

\section{Methods}

For the empirical analysis, a qualitative approach was used that combines within-case analysis with cross-case comparisons [39]. The within-case analysis was derived from process tracing, which involves reconstructing and assessing a series of activities undertaken by entities, leading up to the outcome of interest [40] - in our case, the contemporary conflict surrounding reservoir expansion. Process tracing enables the researcher to unpack a causal story - tracing what follows what - to make within-case inferences about the processes that bind causes and outcomes together [40]. The core elements of a causal mechanism are unpacked theoretically and studied empirically through evidence in the case studies [40].

The cross-case comparison is developed in the discussion section. While process tracing informs us about how things work in one particular case, it is through comparison to other cases that the researcher can generalize- even if only to a small, bounded number of cases. In the comparison, the logic of invariance is used-looking for the presence of similar processes leading to similar outcomes. In other words, it involves only looking at positive cases of the phenomenon you are trying to understand [40].

Data for the two case studies were collected through fieldwork and on-site interviews with representatives from public offices, water utilities, and civil society organizations involved with the current reservoir reoperation, and to the extent possible stakeholders with historical knowledge of the cases. For the Yesa case, 15 semi-structured interviews were undertaken in Spanish with the help of an interpreter, and transcripts were translated into English. In the Gross case, 7 semi-structured interviews were undertaken-fewer due to the abundance of documentation and information available online on the current and historical conflicts. For both cases, archival documents, and academic and grey literature resources were used to complete the interviews.

\section{Case Studies}

\subsection{Gross Reservoir Expansion Project}

This case study will provide an overview of the formation of water institutions and water supply infrastructure along the Front Range of Colorado, focusing on the municipal water provider Denver Water and the events leading to the reoperation of their Gross Reservoir. Four time periods will be discussed, namely, the early water institution-making years and the construction of Gross Reservoir (T1), the balancing of power and rejection of the Two Forks Dam (T2), which led to the proposal for the Gross Reservoir Expansion Project (T3) and its present-day conflict (T4).

\subsubsection{T1 (1954-1970)—Reservoir Construction and the Early Water Institutions}

Gross Reservoir is located on the Eastern Slope of the Rocky Mountains of Colorado (Figure 1 [41]). It was completed in 1954 to store water from a Colorado River tributary on 
the other side of the Continental Divide, through a trans-mountain diversion. The original reservoir has a capacity of 51.5 million cubic meters (MCM), and its primary purpose is municipal water supply for the City of Denver. Although Gross Reservoir also generates hydropower, this use is incidental, operating only when water is being released for the purpose of meeting municipal water-supply needs.

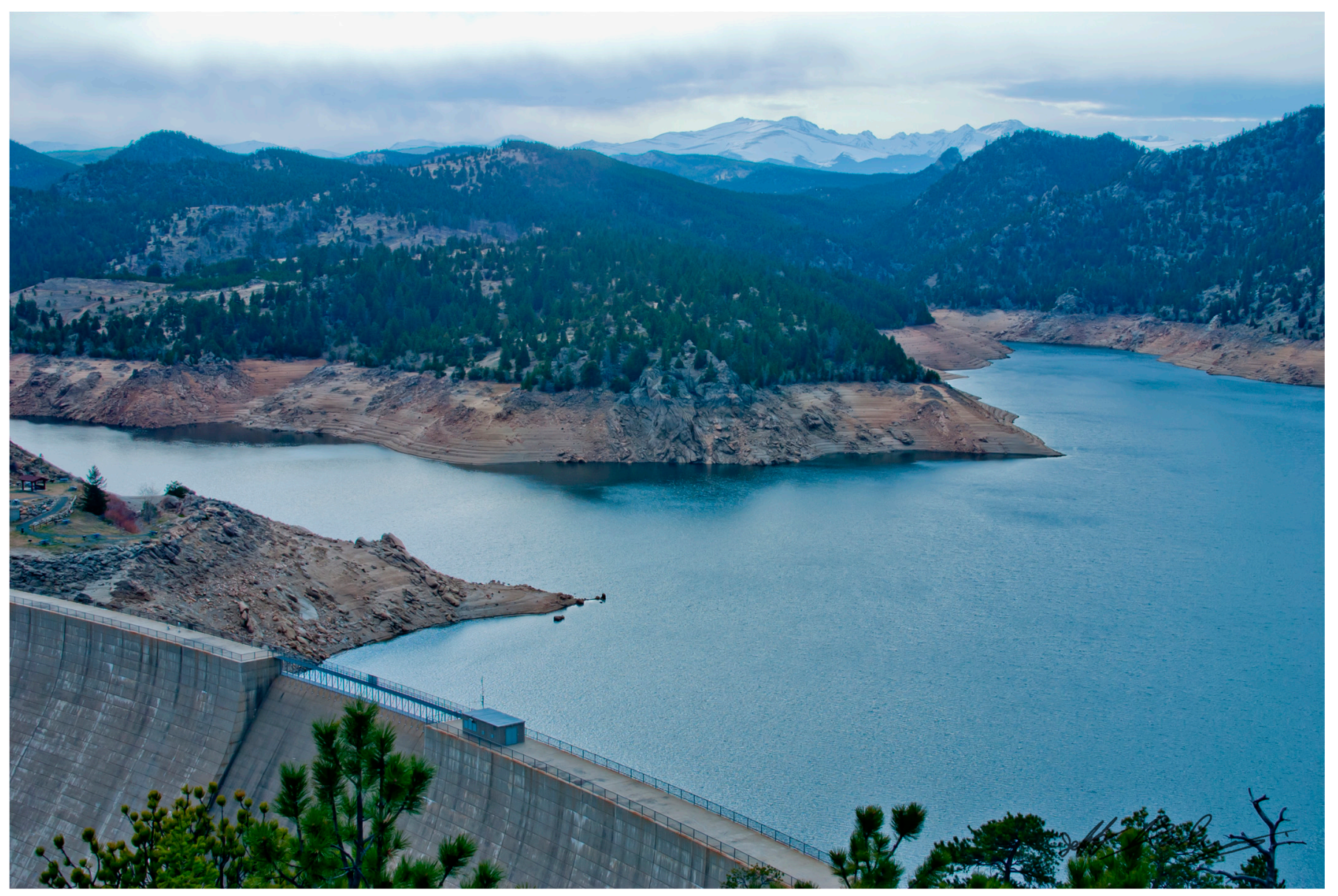

Figure 1. Gross Dam and Reservoir.

Gross Reservoir is owned and operated by Denver Water, a semi-public agency (funded by tariffs, not taxes) created in 1918 and overseen by a Board of Water Commissioners. Although the water is owned by the State of Colorado, users must obtain rights for the water-or in the case of Denver Water, rights for the water they provide to customers. A water right, adjudicated by Colorado's water courts, indicates the amount of water the user is entitled to and the date of its establishment. This latter point is of critical importance; the legal framework of prior appropriation, or "first in time, first in right" is enshrined in the 1876 Colorado Constitution, and dictates that water rights established earlier in time are more senior; more junior rights holders are not allowed to divert water until senior rights are satisfied. To fill Gross Reservoir, Denver Water uses a portion of its 1921 water right to Colorado River water. Importantly, this is considered a senior water right in the basin, as it pre-dates the 1922 Colorado River Compact and the 1938 Upper Colorado River Basin Compact-interstate agreements that allocate water between the upper and lower basin states and within the upper basin states, respectively. Denver Water also owns a 1945 storage right on South Boulder Creek that allows storage of 139.5 MCM of water in Gross Reservoir. As water in the basin grows scarcer due to a combination of factors including climate change and agricultural and population growth, these senior rights become more and more valuable. 
Parallel to securing water rights, Denver Water was amongst the early trans-basin water infrastructure builders. Since the late 1800s, the City of Denver has faced a water supply challenge, as the semi-arid region receives only about $38 \mathrm{~cm}$ of precipitation per year. Whereas most of Colorado's snowmelt and precipitation fall on the Western Slope of the Rocky Mountains, the Eastern Slope is where Denver is located and where most of Colorado's population lives. Prior to the construction of the trans-mountain water diversion tunnels, Denver drew from local rivers and streams (e.g., the South Platte River), but following the Dust Bowl era of the 1930s, Denver Water feared that the reliability of their supply would not manage another such drought (personal communication). Alongside federal agencies such as the United States Bureau of Reclamation (USBR) and the United States Army Corps of Engineers (USACE), Denver Water invested mightily in building trans-mountain tunnels (e.g., Gumlick Tunnel, Harold D. Roberts Tunnel), Western Slope reservoirs (e.g., Dillion Reservoir), and reservoirs that stored water diverted from the Western Slope (e.g., Gross Reservoir).

Up through the 1960s, heavy investment in water infrastructure, often by the federal government, continued, along with the acquisition of water rights to the point where the Colorado River basin water became "overallocated" The prior appropriation institutions ensured that early water users, mostly farmers but also some utilities like Denver Water, would be allocated water over newer uses. Furthermore, as demand for water for urban, agricultural, and industrial uses continued to grow, voluntary water markets emerged as a way to reallocate water [42]. Colorado's first water markets emerged in 1937, and ever since water rights holders were in the advantageous position to either benefit from the security of their use right, vis-à-vis other users, or to lease out or sell their rights to other users on an increasingly lucrative water market [42].

\subsubsection{T2 (1970-1990)—Challenge to Power and Rejection of Two Forks Dam}

These dynamics began to change in the 1970s and 1980s, with the enactment of extensive federal legislation related to the environment, such as the National Environmental Policy Act (1970), the Clean Water Act (1972), the Endangered Species Act (1973), and many others. The new rules stemming from the so-called "green decade" required dam operators and builders to consider environmental impacts and to enhance the participation of citizens and civil society groups [43]. Furthermore, working within the property rights framework, over time the types of water uses considered "beneficial" evolved to include, for example, instream flows, natural lake levels, wetlands, and fish habitats, and were made compatible with the Colorado Constitution. Opportunities to acquire water rights for the preservation of the environment emerged with the 1973 Instream Flow Program. It was also a period marked by the gradual retreat of federal agencies such as the USBR and the USACE in financing new dams, leaving local users on their own to negotiate water supply [43].

It was in this context that in 1981 Denver Water sought to build a new dam-Two Forks - in order to secure urban water supply and put the rest of their Colorado River rights to beneficial use. In addition to the growing water demand in Denver, city officials had been annexing surrounding regions through the 1960s and 1970s-dependent on the utility's ability to store, treat, and deliver water to the metropolitan area. Denver Water developed contracts to provide water to these surrounding suburbs, bolstering demand for the new reservoir [44].

However a project like Two Forks now required a bottom-up review process in order to obtain a federal 404(c) permit under the Clean Water Act [43]. Instead of launching a federal battle with the coalition of (well-known) environmental organizations that opposed the Two Forks Dam, Denver Water invited them to negotiate through the newly formed Denver Metropolitan Water Roundtable. It was to operate by consensus, and to continue discussing alternatives. Following a stalemate in negotiations, in 1990 the federal Environmental Protection Agency ultimately invoked a rarely used provision to veto the 404 permit on the basis of unacceptable adverse impacts. The environmental coalition was successful and plans for the Two Forks Dam project were definitively cancelled. 


\subsubsection{T3 (1990-2014) - Alternative Plan to Expand Storage Capacity at Gross Reservoir}

Without Two Forks to supply the growing metropolitan area, Denver Water embarked on new tactics to secure its future water supply, including conservation (e.g., awarenessraising campaigns, efficiency plans, water recycling) and environmental stewardship (e.g., watershed protection and restoration). The Board of Water Commissioners also made the decision not to extend its geographic service area, instead focusing on supplying water to the growth within its existing boundaries [45]. Collaboration with a wide range of stakeholders also became an important part of the strategy. A case in point is Colorado River Cooperative Agreement, which was signed by Denver Water and 17 other partners, including Western Slope water providers, local governments, and several ski areas. Through this agreement, Denver Water would invest in protecting watersheds in the Colorado Basin (Western Slope) in exchange for allowing (i.e., not opposing) their future water development plans.

The rejection of Two Forks Dam also paved the way for the proposal to expand Gross Reservoir. Firstly, the expansion of Gross Reservoir was a "lower-impact alternative" that had been identified by the environmental coalition during the roundtable discussions on Two Forks (personal communication). Secondly, Denver Water developed an Integrated Resources Plan (IRP) in 1997, with an update in 2002, in order to analyze existing and future water supplies and customer demands. Based on the IRP, and the knowledge that a new structure like Two Forks would not be possible, Denver Water identified the need for enhanced "water supply reliability" "flexibility" "firm yield" and for reducing "vulnerability to natural and man-made disasters" [46]. Thirdly, it was foreseen in the original project documents for Gross Reservoir to raise the dam in the future [47]. The combination of these factors, along with events such as a severe drought in 2002, confirmed for Denver Water the need for more storage.

The reoperation, officially known as the Moffat Collection System Project, began in earnest in 2003 with the preparation of a draft Environmental Impact Statement (EIS). It involved heightening the dam wall from 340 feet to 465 feet, and increasing the storage capacity by about $90 \mathrm{MCM}$, from $51.5 \mathrm{MCM}$ to $140.6 \mathrm{MCM}$ with water diverted from the Colorado and South Platte Rivers [46]. The "Purpose and Need Statement" (2004) provided the official justification for the project, stating that by 2022 Denver Water predicted its average annual water demand would exceed available supplies and that the deficit would grow approximately $50 \mathrm{MCM} /$ year by 2032 . The plan was to meet 47 percent of this demand through conservation, and 53 percent through the expansion of Gross [46]. Based on this document, the Final EIS was issued in 2014, and in 2017 the USACE issued a 404 permit to begin construction.

\subsubsection{T4 (2014-Present)—Water Allocation Conflict Surrounding the Reservoir Expansion Project}

In spite of careful planning, environmental protection measures and coalition-building, the expansion project has been mired in conflict. The opposition comprises citizens, environmental and civil society groups, as well as the administration of Boulder County, in whose jurisdiction the reservoir is located. These actors use multiple tactics, including participating in EIS studies and permit reviews, and voicing their opposition in public hearings. In 2018 an environmental coalition (including a local branch of the Sierra Group, Save the Colorado, WildEarth Guardians, Waterkeepers Alliance, Living Rivers, and The Environmental Group (TEG)) filed a lawsuit claiming that federal agencies failed fully consider the project's environmental impacts before authorizing it, violating several environmental laws (the lawsuit was dismissed by a federal judge in 2021). Since 2019, Boulder County has also opposed the project on a land use permitting issue, which has led to extensive back and forth between Denver Water and the County.

A closer look at some of the key issues reveals how the opposition is probing the very legitimacy of underlying institutions and their informational basis, such as the EIS and the IRP. Arguments question the scientific, technical, and institutional basis of the 
project. Some of the key debates surround Denver Water's stated water needs, the lack of consideration for climate change projections in the EIS, and the wider context of the overallocated Colorado River. Often, competing data and studies are leveraged to cast doubt on the project, reflecting a divergence of underlying values on how to respond to future water stress.

Regarding Denver Water's "Purpose and Need" opponents argue the data used to justify the expansion are outdated. They use Denver Water's own water use and conservation data to show how per capita use has steadily declined despite increased population growth, and also leverage independent studies from universities and consulting firms to substantiate demand forecasts. In an official letter to the Federal Electricity Regulatory Commission (FERC), Boulder County's Attorney General argues against the "staleness of data in the FEIS and the failure to consider the impacts of climate change" and argues that Denver's actual water consumption has not increased at the rate expected nearly two decades ago:

"A Denver Water Gross Reservoir Fact Sheet from 2015 says that it has reduced overall
water use from pre-2002 drought usage by 22 percent. Twenty-two percent of Denver
Water's water supply portfolio of approximately 345,000 acre-feet is 75,900 acre-feet-
more than twice as much as Denver Water expected its shortfall to be in 2035 and more
than four times as much as Denver Water set out to save through conservation. Before
the largest construction project in the history of Boulder County is imposed upon us, the
FERC should require Denver Water to provide more detailed data regarding its water
savings over this period of time and how that compares to what it predicted."

Hundreds, if not thousands, of letters of support to Boulder County, available on their website, use the following text:

"Denver Water doesn't need the water (... ) actual water use has decreased over the last several decades. All across the West, past assumptions linking increased population growth to increased water demand have been proven wrong as people begin to appreciate the connection between water use and their environment. There is no reason to anticipate a different outcome in the Denver Metro area where environmental consciousness is high and water conservation strategies have been put into place."

Another issue surrounds the extent to which climate change projections are being considered in the project design. In 2018, The Environmental Group (TEG) leading the opposition referenced a study from the University of Colorado Boulder, which suggested that if expanded, the reservoir might not be able to be filled due to dwindling water supplies due to climate change, and to downstream obligations (personal communication). Independent consultants have also been engaged for research, through which alternatives to the expansion have been made, such as storing water in an aquifer under the city of Denver (personal communication). TEG has argued that despite the 1600 pages of text, the 2014 EIS does not present any climate change scenarios-an argument that was included in the federal lawsuit. It has also been argued that Denver Water is not appreciating the wider basin context, in that the Colorado River is already overallocated, and obligations to downstream states could threaten their ability to divert water (personal communication). Denver Water responded to these critiques in the "Fact or Fiction" section of the project website; it stated that the contradicting study used a "flawed methodology" with "a different time period, different assumptions, different data and a different model than the hydrologic analysis conducted by independent experts that was published in the Army Corps of Engineers' EIS" which explains the different, and erroneous, results [47].

\subsection{Yesa Regrowth Project}

This case study will provide an overview of the early formation of water institutions and water supply infrastructure in the Ebro River basin, focusing on the basin confederations and their collection and distribution infrastructure, specifically Yesa Reservoir. Four time periods will be discussed, namely, the early water institution-making years leading to 
the reservoir's construction, (T1), then the challenge to power and the rejection of the Ebro Interbasin Transfer (T2), which led to downscaled plans for the reservoir's expansion (T3) and the present-day conflict (T4).

\subsubsection{T1 (1959-1975)—Reservoir Construction and the Early Water Institutions}

Yesa Dam and Reservoir are located in the Pyrenees of Spain, in the Autonomous Communities of Aragon and Navarra (Figure 2). The dam is situated across the Aragon River, an upper tributary of the Ebro River. It was completed in 1959, with a storage capacity of $450 \mathrm{MCM}$. The purpose of the reservoir is to provide water for irrigation through the Bardenas Canal, a private canal belonging to the Comunidad General de Regantes del Canal de las Bardenas (henceforth "'Bardenas irrigators") that irrigates over 80,000 hectares. The reservoir releases water through a separate outlet to the Aragon River.

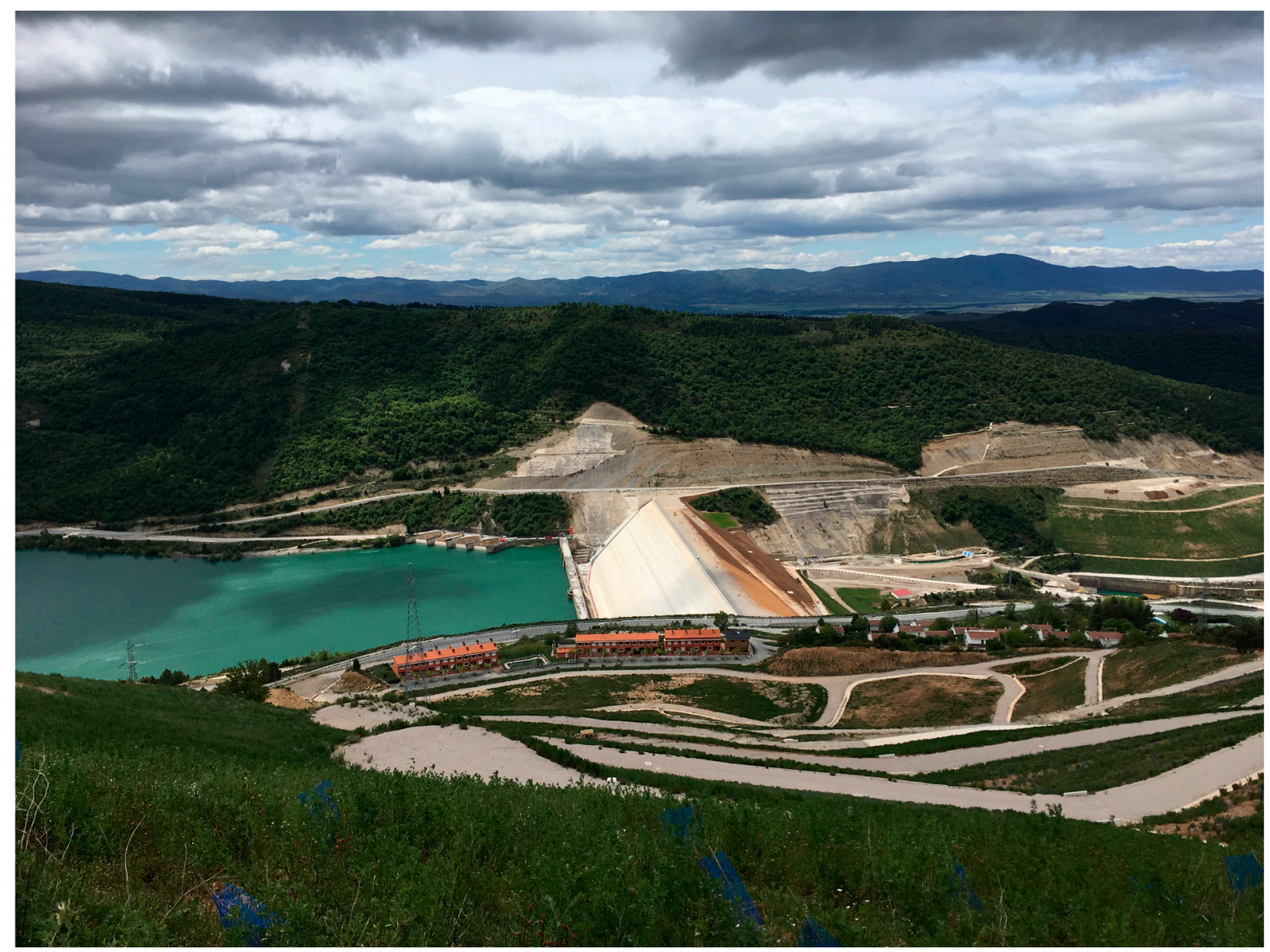

Figure 2. Yesa Dam and Reservoir. The photo was taken in March 2018 by author.

Yesa Reservoir was built during General Franco's political dictatorship (1939-1975)_ an era of intense dam building in Spain. Having lost its colonies abroad, and turning inwards to invest in the nation's economic development, the Spanish State built and financed over 600 large and small dams during this period [21]. The semi-arid and arid climate that characterizes much of the Ebro River basin meant that cycles of drought threatened the economic development of the region, which motivated planners and engineers to build resiliency through infrastructure; the need to control for erratic supply and provide reliable water was a major motivation for the dam builders of the era (personal communication). Whereas the 1920s saw the establishment of the world's first river basin-scale authorities in Spain — at the time called Confederaciones Sindicales Hidrográficas (CSHs), founded on the principles of basin-scale integration, participation of users, and the decen- 
tralization of State functions to the basin level—these were swiftly replaced by centralized top-down management structures under Franco. The CSHs became an appendage of the central division of the Dirección General de Obras Hydrográficas (DGOH)-financed and controlled by the national State. In 1959-the same year that Yesa was completed-the crucial task of water allocation through issuing water concessions was transferred from the $\mathrm{CSH}$ to water commissioners from the DGOH. Water concessions grant use rights for a period of 75 years, and are seldom reviewed and reallocated [48].

As such, in the first half of the 20th century, large landowners and irrigators became major beneficiaries of water concessions and physical connections to water storage infrastructure. The general arrangement was that the State covered the cost of the infrastructure and the landowners reaped the benefits, which represented an extraordinary transfer of value to landowners [21]. In turn, landowners and irrigation communities became strong social and political pillars of the Franco regime, and of the State-led water apparatus more generally. In the case of Yesa, the central State financed the dam, and the Bardenas irrigators financed the network of canals (Bardenas and Sora). The Bardenas irrigation community became the sole beneficiaries of water from Yesa, having successfully blocked proposals to have a hydropower facility installed in the dam (personal communication), and not yet being encumbered by environmental regulations that would emerge in the following decades. Irrigators did pay a fee for water based on volume, but at a low tariff (personal communication).

When the dictatorship ended in 1975, the central State maintained a high degree of control over national water planning. One way was by retaining its authority through basin organizations (renamed Confederación Hidrográficas), structured as part-State and part-confederation of users. Moreover, inter-regional rivers like the Ebro that flow through more than one Autonomous Community would fall under the jurisdiction of the central State. Another way the State retained control in basin planning was through the 1985 Water Law calling for the creation of National Hydrological Plans (NHPs). These plans were to be orchestrated (and largely financed) by the State in order to organize water resources at the national level, with implications for the allocation of funding to the basin scale.

It was through the 1993 and 2001 NHPs that the Yesa Dam and Reservoir became the cornerstone of the massive and controversial Ebro inter-basin transfer. Although the 2001 NHP represented a downscaled version of the 1993 NHP, the concept was the same: interconnect the basins of the Iberian peninsula, and "donate" water from the Ebro, North, Duero, and Tajo rivers to the thirsty and quickly-developing provinces of the south. Addressing the hydrological "imbalance" in the geographic distribution of the national water supply, the 2001 NHP aimed to provide water for urban development, tourism, and recreation, which had become Spain's largest economic sectors [49]. Yesa's storage capacity was set to more than triple from $450 \mathrm{MCM}$ to $1525 \mathrm{MCM}$, representing the largest and most expensive water transfer project in Spanish history [21].

\subsubsection{T2 (1975-2004)—Challenge to Power and Rejection of Ebro Transfer Project}

The transition to democracy did, nonetheless, lead to new decentralized governance structures, and to more forums for participation and debate over environmental issues, including water management. Basin organizations regained their former status as appropriate management units for rivers, and their authority to issue water-use concessions. In 1978 the Autonomous Communities were created, leading to new opportunities for actors at regional, local, and interregional levels, and their different agendas, to seek new spheres of influence and power [50]. Furthermore, Spain acceded to the EU in 2000, and to the Water Framework Directive (WFD) and its River Basin Management Plans, which promote principles of environmental sustainability, subsidiarity, efficiency, and participation. In turn, much of Spain's environmental legislation and policy was developed in the 1990s and 2000s as a result of the transposition of EU norms [51]. Environmental NGOs in Spain eventually became well-known and "professional" policy actors, participating in governmental fora and committees [51]. 
In this context, civil society opposition to the Ebro transfer project took root, and effectively advanced its values and goals. Organizations such as the Defense of the Ebro, COAGRET, and the New Water Culture Foundation (FNCA) advanced arguments based on the values of sustainability and economic rationality-in direct contrast to the content of the NHP, and posing a threat to the traditional beneficiaries of large water infrastructure projects. These values gained traction in national and international consciousness. At the national level, politicians began questioning the assumption that national wealth depended on hydraulic works, and the goal of achieving a "territorial equilibrium" in water distribution [52]. By 2004, the EU was questioning the scientific, technical, and financial feasibility and desirability of the project in official documents [49], and considering blocking project funding [52]. National elections took place in 2004, and resulted in an unexpected win for the socialist party, who immediately suspended, and then cancelled, the NHP and the proposed Ebro inter-basin transfer.

\subsubsection{T3 (2004) - Alternative Plan for Yesa Regrowth}

With the rejection of the massive inter-basin transfer, local stakeholders, including the Government of Aragon and the Confederación Hidrográfica del Ebro (CHE), were quick to prepare a new proposal—one that would still require the expansion of Yesa Reservoir and Dam, but in a scaled-back way that would benefit local stakeholders.

Two institutional commitments in particular drove the current Yesa Regrowth project (El recrecimiento de Yesa in Spanish). The first was the 1992 Aragon Water Pact, through which the Government of Aragon had asserted its claim to an expanded water supply of 6,550 hm3 to double Aragon's irrigated area, which would be accomplished through the construction of many new dams and the expansion of storage at Yesa Reservoir. This agreement was a contract signed by all of Aragon's major political parties (many tied closely to the irrigation community). Its specific provisions on water allocation and infrastructure became embedded in the NHP, but it was also a contract that was binding on the central State. The second commitment was a 2001 Memorandum of Understanding (MoU) between $\mathrm{CHE}$, the City of Zaragoza, and the Government of Aragon to supply drinking water from Yesa Reservoir to Zaragoza-Aragon's largest city. Zaragoza's water supply at the time came from the lower-quality Imperial Canal of the Ebro mainstem. To address water quality concerns and in anticipation of population growth, the MoU outlined that urban residents would secure priority access (demande preferente) to Yesa through a three-stage project. Stage 1 outlined the use of the existing Bardenas and Sora Canals-private infrastructure owned by the irrigators - to transfer water from the reservoir to the outskirts of the city. Stage 2 required building a transit reservoir near the city to manage fluctuations in supply and demand and control water quality (Loteta Reservoir, completed in 2008), and Stage 3 corresponded to the expansion of Yesa Reservoir, deemed necessary to ensure the demande preferente and to ensure the city would contribute to its financing.

Through these agreements, the expansion of Yesa Reservoir was "sold" to the Aragonese as being necessary for the future of the region's irrigation [52,53], and "sold" to Zaragoza as essential for a clean and reliable water supply (personal communication). Moreover, the reoperation was endorsed for "taking advantage of existing infrastructure" and framed as a "compromise" in relation to the failed Ebro Transfer Project (personal communication). The FNCA was one of the dissenting voices on the commission, and proposed alternative plans for agricultural and urban water supply through technical and scientific reports. But their efforts to promote alternative plans for were countered by reports by CHE backing the pro-expansion coalition [52]. The project was approved by vote: Yesa Reservoir's storage capacity would be expanded from $450 \mathrm{hm}^{3}$ to $1079 \mathrm{hm}^{3}$ to serve multiple agricultural, urban, and industrial energy needs in the local basin.

\subsubsection{T4 (2005-Present)_Legitimacy Crisis for CHE over Yesa Regrowth}

The Yesa Regrowth project has been mired in conflict ever since. It has been referred to as "one of the last vestiges of the old water culture" [54] (translated from Spanish), and has 
come under scrutiny on environmental, social, and economic grounds. Opposition comes primarily through the questioning of the scientific, technical, and institutional basis for the project, and through the commissioning of independent studies that cast doubt on the official figures and arguments. Two issues have been a focus in this conflict, characterized by continually competing sources of knowledge, which include the urban water demand projections and the safety of the structure. By looking at each of these issues in turn we can appreciate how the current conflict targets the legitimacy of the institutions that drive the project forward.

Firstly, the urban water demand that was used, in part, to justify the reoperation through the $2001 \mathrm{MoU}$ has repeatedly been called into question, framing the project not only as costly, but also as unnecessary (personal communication). When the MoU was signed in 2001, the estimated future urban water demand for Zaragoza was $132 \mathrm{hm}^{3} /$ year, but demand stabilized at less than half of that figure, at around $60 \mathrm{hm}^{3} /$ year. These contrasts in demand projections have been pointed out in scientific reports written by the University of Zaragoza and the FNCA in 2004 and in 2015 [55], in which they argued the maximum foreseeable demand would not exceed $80 \mathrm{hm} 3 /$ year, and in which they proposed alternatives to Yesa's expansion-options based on values such as modularity, cost effectiveness, and sustainability. When the left-wing party Zaragoza en Común came into power in municipal elections in Zaragoza in 2015, their official position was to decouple the Yesa expansion project from Zaragoza's water supply, deeming the expansion "unnecessary" to meet the city's water needs.

Moreover, Zaragoza has been obtaining its drinking water from Yesa since 2009 through the use of the irrigation canals (Stage 1) and the regulation reservoir outside of the city (Stage 2). CHE argues that Stage 3 of the project (Yesa Regrowth) is required to secure the city's institutional priority to access this water source (demande preferente) (personal communication). Although there is a constitutional priority for municipal drinking water in Spain, and in the EU's WFD, in practice urban users-like other user groups-are expected to cover the costs of their water supply and do not have priority to an improved source until they pay for it. For example, during a drought in 2011, irrigators had priority access to water from Yesa, whereas Zaragoza's water utility took water from the Imperial Canal, which incurred higher treatment costs due to its inferior quality (personal communication).

The reduction in water demand in Zaragoza has been attributed to the population stabilizing at around 700,000 inhabitants, not growing to 1 million as anticipated, and also to a sharp decline in per capita water use. In 1996 the Zaragoza Water Saving City program was initiated, involving extensive awareness-raising campaigns, voluntary commitments to reducing water use, a reduction in non-revenue water loss through leaky pipes, and a revision of the tariff structure to encourage conservation. This was laid out in the Municipal Strategic Plan 1996-2010 with concrete objectives to reduce total city water consumption. The objectives were surpassed due to the significant change in values and behaviors of domestic water users. Furthermore, in 2008 Zaragoza hosted the international water expo and became a globally recognized city for sustainable urban water use.

Another major issue surrounding the Yesa Regrowth project is the safety of the structure. There have been ongoing concerns about the fragility of the surrounding hillsides, with landslides in 2007 and 2015 resulting in tsunami waves in the reservoir. Geological studies commissioned by the Ministry of Works concluded that it is safe to proceed with the expansion, but alternate studies from the University of Zaragoza and the University of Navarra came to different conclusions, and they questioned the parameters used in the models of the official studies, arguing that data are being manipulated and a false image of safety is being promoted [55]. Moreover, addressing these safety concerns has meant that $\mathrm{CHE}$ and the construction companies have no budget; project costs have gone from EUR 113 million in 2001 to EUR 460 million in 2019 [54].

Although the Bardenas irrigators sill support the Yesa expansion project, and benefit from use fees paid to them for the use of their private canals bringing water to Zaragoza and other towns, doubt has been cast on whether the project is even in the long-term 
interest of the irrigation community (personal communication). These arguments are based on the physical limitations of the infrastructure; the limited capacity of the Bardenas Canal, at $54 \mathrm{~m}^{3} / \mathrm{s}$, constitutes a bottleneck that would restrict the promised increases in water during peak irrigation months [55]. Furthermore, it is not certain that there will be enough water in the Aragon River (since the Itioz dam was built upstream in the interim) to ever fill the reservoir as planned (personal communication). Finally, there is a question about the viability of irrigation in much of the basin, where soils have become salty and the lands might not be productive or in demand in the future (personal communication).

\section{Discussion}

In this section the two case studies are synthesized and compared, with the aim of increasing the generalizability of our findings and proposing insights on how to characterize (and therefore potentially address) contemporary conflict surrounding reoperation. In Figure 3 below, a causal story that evolves over time is proposed, reaching back to the construction of the reservoirs in the 1950s and ending with the present-day controversies. The case studies unfold at the meso level of institutional analysis, with some external drivers that come from the macro (national or international) level.

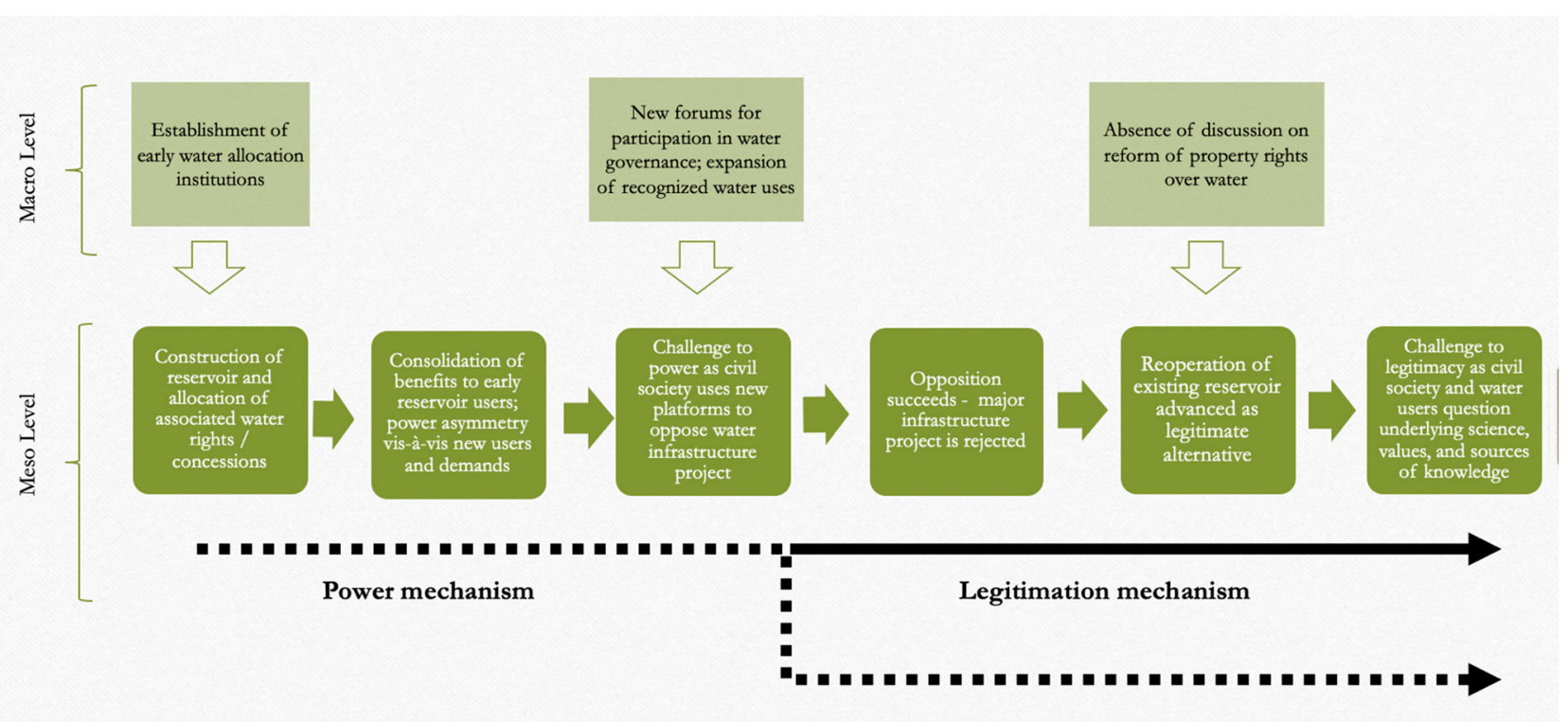

Figure 3. Causal mechanisms schema-from power to legitimation.

In comparing and analyzing the two cases, and based on factors identified in the literature review, we find evidence in support of our three hypotheses. Specifically, the power structure established through early water institutions explains to a large extent how early institutions were perpetuated (H1) and characterizes the type of conflict experienced historically. However, with the onset of stakeholder participation and the expansion of officially recognized water uses, asserting the legitimacy of institutions becomes increasingly important. In the more recent history of the cases, the legitimation mechanism, reproduced because actors believe it is morally just or appropriate, becomes the dominant force behind institutional reproduction $(\mathrm{H} 2)$. As such, the current conflict is primarily a response to the legitimation mechanism, characterized by a divergence in values supported by the proliferation of knowledge, expertise, and opinions on the best way to provide water services (H3). We describe each claim in greater detail further below.

\subsection{Path Dependency and the Challenge to Power}

In both case studies, the establishment of early water institutions were contingent events in that alternative ways of managing water resources could have been foreseen 
at the time. Authorities in the Ebro basin experimented with the world's first-ever river basin organizations in the 1920s and innovated to allocate water between users at the basin level through long-term concessions. In Colorado, the prior appropriation institutions established in the late 19th century diverged from other water allocation methods of the time, but fit the realities of the arid climate and the interests and needs of the early settlers. In both cases, water was perceived as the limiting factor for growth and development, and providing water to early water rights holders became the prerogative of the central government, which required enormous amounts of capital investment and engineering prowess to encourage settlement and economic activity.

Subsequently, these institutional regimes consolidated benefits to early rights and concession holders. Although they did not have special veto powers with which to maintain their advantage, per se, their rights were either issued in perpetuity (Colorado), or were granted for 75 years and were seldom reviewed (Ebro). These actors had the incentive to invest early in distribution and ancillary infrastructure to deliver water to their members or rights holders. New water user groups would face both institutional barriers to access (finite concessions or rights, overallocated resources, limited opportunities to negotiate or contest) as well as physical, infrastructural barriers to access (paying a use fee for distribution infrastructure, or the fact that reservoir sites were taken and canal offtakes established). Meanwhile, institutional innovations such as water markets, albeit more formally in Colorado, only reinforced the powerful position of early water actors, as they gained the possibility of selling or leasing lucrative water rights to other users.

The structure of power became more pluralist in the 1970s-1990s in the case studies, and less dominated by a small number of water uses and users. New policies on the environment (e.g., species protection and environmental flow regulations), on public participation (e.g., due diligence and EIAs), and new multilevel governance structures (e.g., European Union, river basin management plans) brought in more diverse views and values to weigh in on water governance and allocation questions. Moreover, the list of recognized water uses expanded, with water use rights being secured for the environment, recreation, habitats, and other previously neglected uses. At the meso level of the cases, this new inclusiveness led to the rejection of large-scale infrastructure projects- the Ebro transfer project, and the Two Forks Dam project. As such, the power mechanism of institutional reproduction, working through the inclusion of early users and exclusion of later users in the governance system, goes a long way in explaining how the early institutional path is maintained, and in understanding the historical conflict in the case studies.

\subsection{Emergence of Legitimation Mechanism}

The power mechanism of institutional reproduction does not disappear in the cases, as depicted in Figure 3. This is most clearly evidenced by the continuation of property rights systems, which have not undergone any significant reform. As also found by Heinmiller [9], new water uses, such as for environmental conservation, can simply be added on to existing apportionment institutions. We argue, however, that legitimacy comes to dominate as a mechanism of institutional reproduction precisely because the challenge to power results in heightened stakeholder involvement and a new need to (continuously) justify projects vis-à-vis alternatives. In the new operating context characterized by a plurality of voices, diverse recognized water uses and users, and a prerogative for multifunctionality of water infrastructure, the legitimation mechanism-working on decision-makers and public perceptions of existing institutions as legitimate [16] - becomes necessary for water suppliers to maintain their advantage over alternative institutional arrangements.

In the case of the Yesa Regrowth project, we have the rapid reorganization and downscaling of the project in 2004, and CHE asserting its contractual commitments to the irrigation community and urban residents in Aragon. Aragon's agricultural water needs are put forward as concrete, local, and urgent (as per the 1992 Water Pact) in contrast to the extravagant plans to support tourist development in the south- "the common fight against transfers" [52]. CHE also advances its new "multipurpose" project through the 
need for an improved drinking water source for urban residents (as per the $2001 \mathrm{MoU}$ ), and uses its commitments to the WFD's drinking water quality requirements to support its supply-side approach (personal communication). CHE goes to great lengths to justify the expansion as their rightful duty, honoring local concessions and contracts, and advancing the legitimacy of their exploitation boards to allocate the resource.

In the Gross Reservoir case, Denver Water's values and approach to water supply significantly change following the rejection of Two Forks, which they refer to as their "crucible" (personal communication). They embrace and act on conservation and collaboration efforts, and put forward extensive impact mitigation measures to legitimize the expansion projectfor instance, emphasizing its "net environmental benefit" to the state's water quality [47]. In this case, Denver Water acknowledges the need to combine supply and demand side measures to maintain their legitimacy, while asserting their critical role-the oldest water utility in the state-to deliver "safe, reliable water to the more than 1.5 million residents in our service area today and many of the projected millions who will call Colorado home in the decades to come" [45]. Gross expansion is further justified in juxtaposition to impacts that would have been engendered by the Two Forks Dam, and by the fact that they are lawful (i.e., "correct" "legitimate") holders of property rights to the waters of the Colorado and Platte tributaries.

Through these examples, and other details in the case study descriptions, we observe how water suppliers enter an era of asserting their legitimacy in light of prevailing challenges by explicitly advancing their values and their presumed duties as service providers.

\subsection{Conflict Surrounding Contemporary Reoperation Projects—Legitimacy Challenge}

The current controversies surrounding the expansion of Gross Reservoir in Colorado and Yesa Reservoir in Aragon can be characterized as legitimacy crises for water providers, explained to a large extent by the relatively quickly changing values of the water users to whom they are accountable. Under the legitimacy mechanism, institutions may become less consistent with the values of actors; change comes from changes in values or subject beliefs [16]. Key issues in the contemporary conflicts are not about power and exclusion from decision-making, but about the role, appropriateness, and scientific basis of certain institutions to deliver services. The questions framing the debate are the following: Who should be providing the data upon which decisions are made? Whose study is more accurate, and therefore more legitimate? What is the truth about water use and supply? Who are the legitimate users of the reservoir? This is notably different from debates of the past, which were better characterized by the need to recognize and incorporate diverse uses and users, and to balance heavy top-down management with more participatory processes.

The trend towards the democratization of scientific policy advice represents evidence of an increasing demand for legitimacy [56]. This is certainly present in the cases, but instead of it leading to greater trust in decision-making and the scientific arguments that inform them, the democratization of scientific policy advice is used to cast doubt and fuel the debates. Opposition groups seek out alternative expertise and studies to fact-check project justifications and to provide alternate perspectives and ways forward. Through these exchanges, water suppliers' values such as system balance, system reliability, redundancy, dependability, and the need to plan for extremes and the long-term are pitted against (sometimes in spite of efforts to the contrary) values of ecological and social sustainability, economic rationality, and more modular ways of thinking about water infrastructure. Even in the Gross Reservoir case, where Denver Water's values have evolved significantly over time, there is still a chasm with widely-held public values that can seemingly not be overcome. Although differing values play a key role in both the historical conflicts related to power imbalance and the contemporary conflicts related to legitimacy crises, the solutions to the latter remain elusive for the time being. 


\section{Conclusions}

This paper analyzes two contemporary cases of conflict surrounding the reoperation of existing reservoirs by placing them in their historical context: the Yesa Reservoir in the Ebro basin, Spain, and the Gross Reservoir in the Colorado basin, USA. Through a historical and comparative approach, and using the concept of path dependency, we provide insights into both historical and present-day controversies, and connect them in a causal story that evolves over many decades. We argue and present empirical evidence of a transition in the dominant mechanism of institutional reproduction from power to legitimacy in the two cases, and claim that the current conflict can be characterized as a legitimacy crisis for water service providers. We do not negate the presence of structural power imbalance in the present conflicts; rather; attention is brought to dominance of the legitimacy challenge facing water service providers in an age of information and participation-where the divergence of values can seem irreconcilable and different sources of knowledge often compete. This research sheds light on some of the contemporary challenges faced by water utilities, and it would be fruitful for future research to examine whether and how other contemporary water conflicts are ultimately rooted in legitimacy issues. Future academic and applied research could also work towards addressing such legitimacy crises, for example, by investigating to what extent differing values can be reconciled, or to what extent trade-offs between values and reliability of supply might be acceptable to users.

Funding: The fieldwork for this study was funded by the UNESCO Chair for Hydropolitics at the University of Geneva, and the Environmental Governance and Territorial Development (GEDT) Hub at the University of Geneva.

Institutional Review Board Statement: Not applicable.

Informed Consent Statement: Informed consent was obtained from all subjects interviewed for the study.

Data Availability Statement: Not applicable.

Conflicts of Interest: The authors declare no conflict of interest. 


\section{Appendix A. Mechanisms of Institutional Reproduction from Path Dependency Studies}

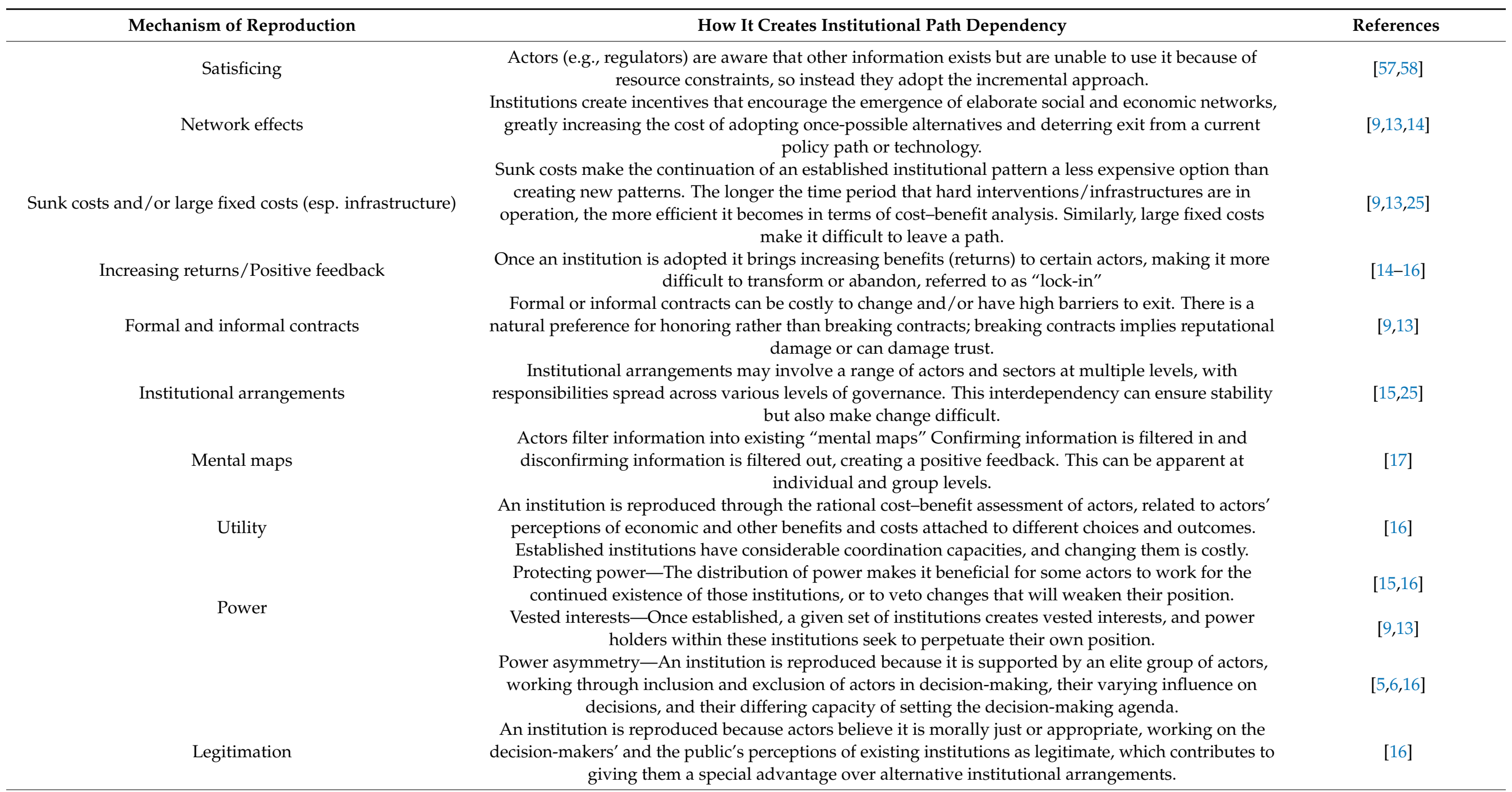


Mechanism of Reproduction

Social values

Memory (esp. social ecological memory)

Adaptive expectations

Social expectations

Learning effects

\section{How it Creates Institutional Path Dependency}

References

Social values are valuations people make (individuals or groups) about what is important; they can influence whether an institutional option is considered successful and just or unsuccessful and maladaptive.

The accumulated experiences, knowledge, and history of management (e.g., of an ecosystem) held by various actor groups can generate institutional inertia.

Actors make their actions meet their expectations (e.g., confidence in technology increases with more adoption, which leads to more adoption and lock-in).

Past experiences can lead decision-makers and the general public to have certain expectations about appropriate institutions.

Knowledge for decision-making is deployed within institutions, through people employed with specific qualifications (e.g., engineers). A "correct" way of defining and addressing problems is established. Such learning processes within institutions mean decisions often follow the already chosen path.

Source: Compiled by author from referenced studies. 


\section{References}

1. World Commission on Dams. Dams and Development: A New Framework for Decision-Making. The Report of the World Commission on Dams; Earthscan: London, UK, 2000.

2. Ansar, A.; Flyvbjerg, B.; Budzier, A.; Lunn, D. Should we build more large dams? The actual costs of hydropower megaproject development. Energy Policy 2014, 69, 43-56. [CrossRef]

3. Lavers, T.; Dye, B. Theorising the Political Economy of Dams: Towards a Research Agenda, FutureDAMS Working Paper 001; The University of Manchester: Manchester, UK, 2019.

4. Scott, C.A.; Shrestha, P.P.; Lutz-Ley, A.N. The re-adaptation challenge: Limits and opportunities of existing infra-structure and institutions in adaptive water governance. Curr. Opin. Environ. Sustain. 2020, 44, 104-112. [CrossRef]

5. Turley, L.; Bréthaut, C.; Pflieger, G. Institutions for reoperating reservoirs in semi-arid regions facing climate change and competing societal water demands-Insights from Colorado. Water Int. 2021. Forthcoming.

6. Pierson, P. Increasing Returns, Path Dependence, and the Study of Politics. Am. Polit. Sci. Rev. 2000, 94, 251-267. [CrossRef]

7. Ingram, H.; Fraser, L. Path dependency and adroit innovation: The case of California water. In Punctuated Equilibrium and the Dynamics of US Environmental Policy; Yale University Press: London, UK, 2006; pp. 78-109.

8. Marshall, G.R.; Alexandra, J. Institutional Path Dependence and Environmental Water Recovery in Australia's Murray-Darling Basin. Water Altern. 2016, 9. Available online: https://www.water-alternatives.org/index.php/alldoc/articles/vol9/v9issue3/3 23-a9-3-16/ file (accessed on 13 August 2021).

9. Heinmiller, T. Path dependency and collective action in common pool governance. Int. J. Commons 2009, 3. [CrossRef]

10. Garrick, D.E. Water Allocation in Rivers under Pressure: Water Trading, Transaction Costs and Transboundary Governance in the Western Us and Australia; Edward Elgar Publishing: Northampton, MA, USA, 2015.

11. Closas, A. 'Praying for rain': A case of drought mismanagement in Barcelona (2007-2008). Water Altern. $2020,13,902$.

12. Hassenforder, E.; Barone, S. Institutional arrangements for water governance. Int. J. Water Resour. Dev. 2018, 35, 783-807. [CrossRef]

13. Kay, A. A Critique of the Use of Path Dependency in Policy Studies. Public Adm. 2005, 83, 553-571. [CrossRef]

14. Pierson, P. When Effect Becomes Cause: Policy Feedback and Political Change. World Polit. 1993, 45, 595-628. [CrossRef]

15. Sorensen, A. Taking path dependence seriously: An historical institutionalist research agenda in planning history. Plan. Perspect. 2015, 30, 17-38. [CrossRef]

16. Mahoney, J. Path dependence in historical sociology. Theory Soc. 2000, 29, 507-548. [CrossRef]

17. North, D.C. Institutions, Institutional Change and Economic Performance; Cambridge University Press: Cambridge, UK, 1990.

18. Pflieger, G.; Pattaroni, L.; Kaufmann, V.; Jemelin, C. How Does Urban Public Transport Change Cities? Correlations between Past and Present Transport and Urban Planning Policies. Urban Stud. 2009, 46, 1421-1437. [CrossRef]

19. Martin, R.; Sunley, P. Path dependence and regional economic evolution. J. Econ. Geogr. 2006, 6, 395-437. [CrossRef]

20. Molle, F.; Mollinga, P.P.; Wester, P. Hydraulic bureaucracies and the hydraulic mission: Flows of water, flows of power. Water Altern. 2009, 2, 328-349.

21. Swyngedouw, E. Liquid Power: Contested Hydro-Modernities in Twentieth-Century Spain; MIT Press: Cambridge, MA, USA, 2015; pp. 1-320.

22. Shapiro, A.; Summers, R. The evolution of water management in Alberta, Canada: The influence of global management paradigms and path dependency. Int. J. Water Resour. Dev. 2015, 31, 732-749. [CrossRef]

23. Anderson, M.B.; Ward, L.C.; Gilbertz, S.J.; McEvoy, J.; Hall, D.M. Prior appropriation and water planning reform in Montana's Yellowstone River Basin: Path dependency or boundary object? J. Environ. Policy Plan. 2017, 20, 198-213. [CrossRef]

24. Bukowski, J. Spanish Water Policy and the National Hydrological Plan: An Advocacy Coalition Approach to Policy Change. South Eur. Soc. Polit. 2007, 12, 39-57. [CrossRef]

25. Parsons, M.; Nalau, J.; Fisher, K.; Brown, C. Disrupting path dependency: Making room for Indigenous knowledge in river management. Glob. Environ. Chang. 2019, 56, 95-113. [CrossRef]

26. Schweizer, R.; Bréthaut, C. From the Promises of International Water Management Trends to the Reality of Policies and Practices: Some Conclusive Thoughts. In A Critical Approach to International Water Management Trends; Springer Science and Business Media LLC: Berlin/Heidelberg, Germany, 2017; pp. 269-293.

27. Melnychuk, N. Assessing Legitimacy within Collaborative Water Governance: How, When, and by Whom? 2017. Available online: http:/ / hdl.handle.net/10012/12579 (accessed on 13 August 2021).

28. Gearey, M.; Jeffrey, P. Concepts of legitimacy within the context of adaptive water management strategies. Ecol. Econ. 2006, 60, 129-137. [CrossRef]

29. Wester, P.; Merrey, D.J.; de Lange, M. Boundaries of Consent: Stakeholder Representation in River Basin Management in Mexico and South Africa. World Dev. 2003, 31, 797-812. [CrossRef]

30. Lieberherr, E. Trade-offs and Synergies: Horizontalization and legitimacy in the Swiss wastewater sector. Public Manag. Rev. 2014, 18, 456-478. [CrossRef]

31. Orr, C.J.; Adamowski, J.F.; Medema, W.; Milot, N. A multi-level perspective on the legitimacy of collaborative water governance in Québec. Can. Water Resour. J. Rev. Can. Ressour. Hydr. 2015, 41, 353-371. [CrossRef]

32. Scharpf, F.W. Governing in Europe: Effective and Democratic? Oxford University Press: Oxford, UK, 1999. 
33. Wolf, K.D. Contextualizing normative standards for legitimate governance beyond the state. In Political and Societal Implications; Jürgen, R.G., Gbikpi, B., Eds.; Participatory Governance: Opladen, Germany, 2002; pp. 35-50.

34. Schmidt, V.A. Democracy and Legitimacy in the European Union Revisited: Input, Output and 'Throughput'. Polit. Stud. 2013, 61, 2-22. [CrossRef]

35. Melnychuk, N.; de Loë, R. Legitimacy assessment throughout the life of collaborative water governance. Environ. Policy Gov. 2020, 30, 14-28. [CrossRef]

36. Beetham, D. The Legitimation of Power; Macmillan International Higher Education: London, UK, 2013.

37. Giddens, A. The Constitution of Society, Outline of the Theory of Structuration; University of California Press: Berkeley, CA, USA, 1984.

38. Thelen, K. How Institutions Evolve: The Political Economy of Skills in Germany, Britain, the United States, and Japan; Cambridge University Press: Cambridge, UK, 2004.

39. George, A.L.; Bennett, A. Case Studies and Theory Development in the Social Sciences; The MIT Press: Cambridge, MA, USA, 2005.

40. Beach, D.; Pedersen, R.B. Process-Tracing Methods, 2nd ed.; University of Michigan: Ann Arbor, MI, USA, 2019.

41. Bailey, J. Gross Reservoir Dam [6 May 2011]. Available online: https://www.flickr.com/photos/mbabailey/5730327252/in/ photolist-9JnqDJ-a8Qd1A-cfwieb-pCYAgk-Aitkqe-8tc4u-hCLnwD-9Gc3iN-5ya6SV-5ya77c-9JZsoK-5yew4y-9JZoN8-9JZsD4-9 JZsUc-5ya8sz-5ya9gx-9JZsh4-5ya472-5ya9HD-5yeuDb-9JZsKX-Aga1GZ-5ya89n-5yevHb-9zrmUB-5ya8zT-zX6zbj-9zrmNa9zrmAt-XW2ou6-2joWWWs-2hUzqar-4M8EJu-25bDw9v-2kxxdRu-2jcQ72X-MsidiR-2irWXDQ-tgGGAy-qfLT6N-D4Sd7U6Rcohn-iaZ434-2kC7ARn-i4ExgJ-2kDW5px-ot19NY-25di3Rc-73YgWP (accessed on 13 August 2021).

42. Michelsen, A.M. Administrative, Institutional, and Structural Characteristics of an Active Water Market. JAWRA J. Am. Water Resour. Assoc. 1994, 30, 971-982. [CrossRef]

43. Luecke, D.F. Two Forks: The rise and fall of a dam. Nat. Resour. Environ. 1999, 14, $24-69$.

44. Ellison, B.A. Intergovernmental relations and the advocacy coalition framework: The operation of federalism in Denver water politics. Publius: J. Fed. 1998, 28, 35-54. [CrossRef]

45. Denver Water Website. About Us, History, Timeline. 2021. Available online: https://www.denverwater.org/about-us/history/ timeline (accessed on 13 August 2021).

46. Moffat Collection System Project, Environmental Impact Statement (EIS), Executive Summary. 2014. Available online: https: //www.circleofblue.org/wp-content/uploads/2014/04/Army-Corps_Moffat-FEIS.pdf (accessed on 13 August 2021).

47. Gross Reservoir Expansion Project Website. Fact or Fiction? 2021. Available online: https://grossreservoir.org/about-the-project/ fact-or-fiction/ (accessed on 13 August 2021).

48. Hernández-Mora, N. "SLIDES: Water Allocation and Water Markets in Spain" Coping with Water Scarcity in River Basins Worldwide: Lessons Learned from Shared Experiences. In Proceedings of the Martz Summer Conference, Boulder, CO, USA, 9-10 June 2016.

49. Hernández-Mora, N.; Ituarte, L.D.M.; La-Roca, F.; La Calle, A.; Schmidt, G. Interbasin Water Transfers in Spain: Interregional Conflicts and Governance Responses. In Globalized Water; Springer Science and Business Media LLC: Berlin/Heidelberg, Germany, 2014; pp. 175-194.

50. De Stefano, L.; Hernandez-Mora, N. Multi-level interactions in a context of political decentralization and evolving water-policy goals: The case of Spain. Reg. Environ. Chang. 2018, 18, 1579-1591. [CrossRef]

51. Muñoz, L.; Moya, D. NGOs environmental legal mobilization and their access to the Spanish Supreme Court. Oñati Socio-Legal Ser. 2019, 9, 308-332. [CrossRef]

52. Murillo, L.C. Conflictos del agua en Aragón: Yesa y Matarraña, dos casos emblemáticos en la resolución de conflictos. Ambiente Desarro. 2012, 16, 9-24.

53. Arrojo, P.; Gracia, J.J.; Martínez Gil, F.J.; Nicolau, J.M.; Solana, M. Recrecimiento de Yesa: El abastecimiento a Zaragoza como excusa para los trasvases. Serie informes. Nueva Cult. Agua 1999, 40p. Available online: http://www.yesano.com/informes/ informe_yesa.pdf (accessed on 13 August 2021).

54. WWF España; Amigos de la Tierra; Ecologistas en Acción; Greenpeace; SEO/BirdLife; Asociación Río Aragón. Recrecimiento de Yesa: Una Apuesta por el Pasado que Olvida el Futuro. 2020. Available online: https://wwfes.awsassets.panda.org/downloads/ informe_recrecimiento_de_yesa_una_apuesta_por_el_pasado_que_olvida_el_futuro.pdf?55580/Pedimos-al-MITECORDque-descarte-el-recrecimiento-del-mayor-pantano-del-Pirineo-incompatible-con-la-transicion-ecologica (accessed on 13 August 2021).

55. Gracia, J.-J.; Arrojo, P.; Casas, A. Alternativas Al Recrecimiento De Yesa para El Sistema De Riegos De Bardenas. Fund. Nueva Cult. Agua 2015. [CrossRef]

56. Pregernig, M.; Bocher, M.; Hogl, K.; Kvarda, E.; Nordbeck, R. Normative and Analytical Perspectives on the Role of Science and Expertise in Environmental Governance. In Environmental Governance; Edward Elgar Publishing: Northampton, MA, USA, 2013.

57. Simon, H. Models of Man: Social and Rational; Wiley: New York, NY, USA, 1957.

58. Kirk, E.A.; Reeves, A.D.; Blackstock, K.L. Path dependency and the implementation of environmental regulation. Environ. Plan. C Gov. Policy 2007, 25, 250-268. [CrossRef]

59. Nykvist, B.; Von Heland, J. Social-ecological memory as a source of general and specified resilience. Ecol. Soc. 2014, 19, 47. [CrossRef] 